\title{
HOW WELL DOES NATURA 2000 PROTECT THREATENED STONE CRAYFISH IN CROATIA?
}

\section{Leona Lovrenčić ${ }^{1}$, Martina Temunović ${ }^{2}$ \& Ivana Maguire ${ }^{*}$}

${ }^{1}$ University of Zagreb, Faculty of Science, Department of Biology, Rooseveltov trg 6, Zagreb, Croatia ${ }^{2}$ University of Zagreb, Faculty of Forestry and Wood Technology, Svetošimunska cesta 25, Zagreb, Croatia

Lovrenčić, L., Temunović, M. \& Maguire, I.: How well does NATURA 2000 protect threatened stone crayfish in Croatia? Nat. Croat., Vol. 29, No. 2, 241-253, 2020, Zagreb.

The stone crayfish Austropotamobius torrentium (Schrank, 1803) is a threatened native European freshwater crayfish species for which Natura 2000 network represents the most important conservation effort at the European level. In Croatia, there are altogether 25 Natura 2000 sites defined specifically for this species. In the present study, we aimed to assess the effectiveness of Natura 2000 sites in preserving stone crayfish diversity through gap analysis, a GIS-based approach that overlays species distribution data on a map of designated Natura 2000 sites. Our results showed that the existing Natura 2000 network in Croatia encompasses most of the areas with a high diversity of A. torrentium; currently designated sites harbour $73.3 \%$ of recorded $A$. torrentium populations. Future conservation planning efforts, and possible expansion of Natura 2000, should be focused on newly discovered $A$. torrentium populations that present divergent evolutionary lineages.

Key words: Austropotamobius torrentium, Astacidae, gap analysis, conservation planning, biodiversity conservation

Lovrenčić, L., Temunović, M. \& Maguire, I.: Koliko dobro postojeća Natura 2000 mreža štiti ugroženog potočnog raka u Hrvatskoj? Nat. Croat., Vol. 29, No. 2, 241-253, 2020, Zagreb.

Potočni rak Austropotamobius torrentium (Schrank, 1803) je ugrožena autohtona europska vrsta slatkovodnog raka porodice Astacidae za kojeg mreža Natura 2000 predstavlja najvažniju inicijativu u konzervaciji na europskoj razini. U Hrvatskoj uključuje 25 područja određenih posebno za ovu vrstu. Cilj ovog istraživanja je bio procijeniti učinkovitost Natura 2000 područja u očuvanju raznolikosti potočnog raka kroz gap analizu koja se temelji na preklapanju karata rasprostranjenosti ove vrste i Natura 2000 određenih područja korištenjem GIS programskog paketa. Rezultati su pokazali da postojeća mreža Natura 2000 u Hrvatskoj obuhvaća 73,3\% populacija potočnog raka te uključuje i područja njegove najveće raznolikosti. Pri izradi budućih planova konzervacije ove vrste i mogućih proširenja Natura 2000 područja posebnu pažnju treba obratiti na novootkrivene populacije koje ujedno predstavljaju evolucijski divergentne linije.

Ključne riječi: Austropotamobius torrentium, Astacidae, gap analiza, konzervacijski planovi, zaštita bioraznolikosti

\section{INTRODUCTION}

Austropotamobius torrentium (Schrank, 1803), the stone crayfish, is a cold-adapted crayfish species native to smaller pristine water bodies related to karstic formations at higher altitudes in central and south-eastern Europe (Kouba et al., 2014). In Croatia it

\footnotetext{
* corresponding author: Ivana Maguire (imaguire@biol.pmf.hr)
} 
is distributed mainly in water bodies of the Black Sea drainage, with a few populations in the Adriatic Sea basin (MAguire et al., 2018). It is characterised by complex evolutionary history and high genetic diversity represented by nine distinct mitochondrial phylogroups, seven of them inhabiting freshwaters of Croatia (KLOBuČAR et al., 2013; PÂRvUlescu et al., 2019; Lovrenčić et al., 2020). Nowadays numerous populations belonging to different phylogroups are threatened by human activities and protection of them is indispensable (MAGUiRe et al., 2018).

Stone crayfish conservation activities ought to secure the long-term survival of species by taking into account the complexity of natural ecosystems involving all levels of biological diversity and organisation (Rodrigues et al., 2004; JANTKE et al., 2013). Therefore, the development of broad-scale conservation networks of protected areas is considered to be a fundamental step for preventing future biodiversity loss through enabling the continuation of eco-evolutionary processes (Poiani et al., 2000; Rodrigues et al., 2004; MaOirono et al., 2006) and adaptation of species to changes in the distribution of suitable habitats under the ongoing climate change (ArAújo et al., 2011). Effective preservation includes: the evaluation of the existing conservation areas in the representation of biodiversity, identification of underrepresented elements, and recommendation how the conservation could be enhanced (AbELLAN \& SANCHEz-Fernandez 2015; Bosso et al., 2016). For this reason, systematic approaches to conservation planning for protecting $A$. torrentium should be focused on the preservation of its unique genetic diversity so as it ensures adaptive potential and evolutionary response to the fast changes in the environment and pressures on its habitats.

One of the most important conservation efforts at European level is the Natura 2000 network. Natura 2000 is the largest network of protected areas in the world, established by the European Union (EU) with the aim of ensuring the long-term survival of its most valuable and threatened species and habitats. The network includes Special Protection Areas (SPAs) designated under the Birds Directive 2009/147/EC and Special Areas of Conservation (SACs) designated under the Habitats Directive 1992/43/EEC. The effectiveness of this network in representing biodiversity has been assessed in numerous studies at global or regional scales through gap analysis (Rodrigues et al., 2004; JANTKE et al., 2011; Verovnik et al., 2011; Gruber et al., 2012; Bagella et al., 2013; Abellan \& Sanchez-Fernandez, 2015; Maiorano et al., 2015; Orlikowska et al., 2016), and the outcomes of these studies vary.

Gap analysis is a GIS-based approach for assessing the effectiveness of protected areas in representing species diversity by comparing the distribution of species with the extent of the conservation network (Rodrigues et al., 2004; JENNINGs, 2000; Bosso et al., 2016). It is a widely implemented and useful tool for the identification of different elements (e.g., species, habitats, ecosystems) that require greater and/or stronger protection (Jennings, 2000; Scott et al., 2001; Oldfield et al., 2004; Dietz \& Czech, 2005; O'DeA et al., 2006).

Croatia has one of the most extensive Natura 2000 networks in Europe covering $36.73 \%$ of the land territory and $15.42 \%$ of the seashore. Moreover, Natura 2000 in Croatia includes 25 designated sites (Sites of Community Importance - SCI) for $A$. torrentium that were defined according to historical and recent data on the distribution, size of populations, and abundance of this vulnerable species (MAGUiRe et al., 2011). The state members propose their SCI areas to the European Union and once approved, 
they can be appointed as SACs (Special Areas of Conservation) that are targeted to important measures in order to conserve the habitats and species in question.

From a practical conservation perspective, it is critical to evaluate the extent to which present and future protected areas cover $A$. torrentium diversity in freshwater ecosystems. Therefore, the aim of this research was to assess the effectiveness of the Natura 2000 network in preserving stone crayfish diversity in Croatia, through performing gap analysis that overlays $A$. torrentium distribution data on a map of Natura 2000 sites. This study provides the first comprehensive analysis of the effectiveness of conservation areas in protecting the endangered stone crayfish in Croatia.

\section{MATERIAL AND METHODS}

\section{Study area}

The karstic freshwaters of the north-central Dinarides in the western part of the Balkans are considered the primary centre of radiation of the stone crayfish, harbouring the highest number of lineages and the greatest genetic diversity, while diversity outside this area is greatly reduced (TRONTELj et al., 2005; KLOBuČAR et al., 2013; BERGER et al., 2018; PÂrvulescu et al., 2019; Lovrenčić et al., 2020) (Fig. 1). Nowadays the phylogeographic pattern of the stone crayfish is connected to the palaeo-hydro-geomorphological and climatic history of the Balkan Peninsula. The karstification processes fragmented the palaeohydrography of the area, which facilitated geographical isolation and enabled allopatric speciation shaping this species' intricate evolution (Trontelj et al., 2005; KLOBUČAR et al., 2013). Because habitat deterioration, decline in water quality, climate change and the spreading of invasive alien crayfish species and their pathogens caused populations decline throughout its distribution range (Kouba et al., 2014; Maguire et al., 2018),

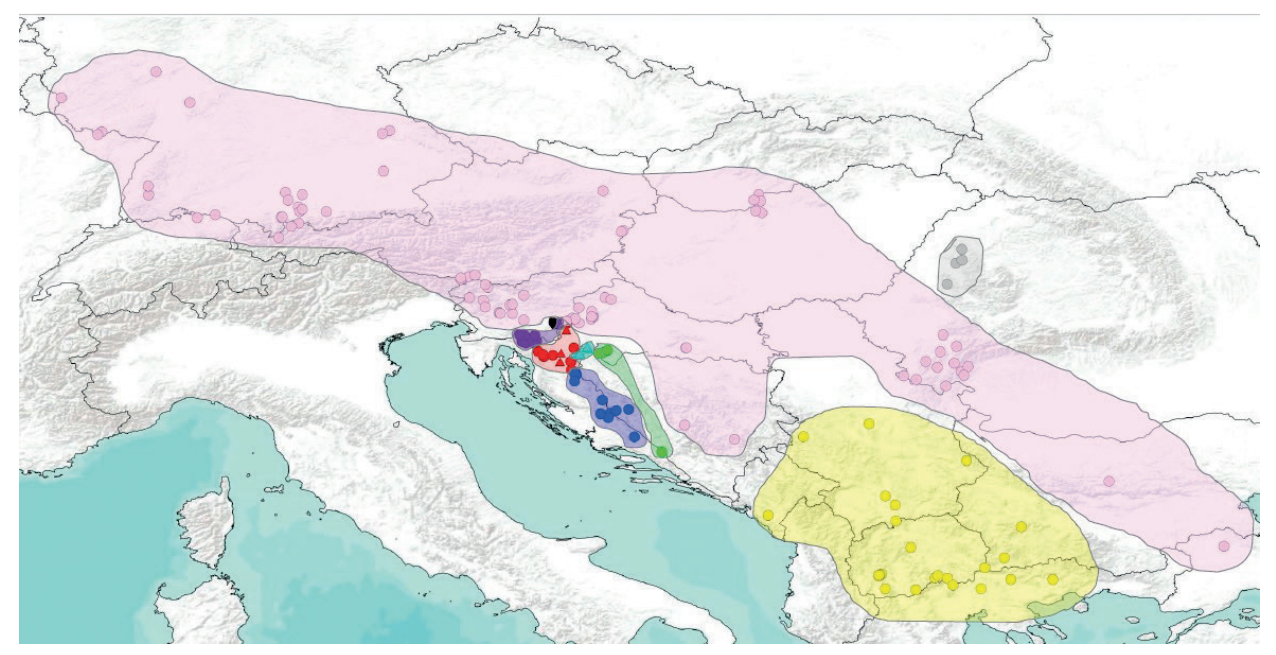

Fig. 1. Distribution of Austropotamobius torrentium phylogroups in Europe. Colours depict distribution of different mitochondrial phylogroups: pink - central and south-eastern Europe (CSE), purple - Gorski Kotar (GK), blue - Lika and Dalmatia (LD), red - Žumberak, Plitvice and Bjelolasica (ŽPB), green - Banovina (BAN) and black - Zeleni Vir (ZV), yellow - southern Balkans (SB), grey - Apuseni Mountain (APU) and turquoise - Kordun (KOR, new phylogroup, Lovrenčić et al., 2020). 
the stone crayfish is listed as threatened and protected in Appendix III of the Bern Convention and Annexes II and V of the EU Habitats Directive (92/43/EEC and 97/62/EU). Furthermore, it was declared a Natura 2000 species in 2013.

\section{Species distribution data}

This study was performed on a dataset that included previously published work on the distribution of $A$. torrentium in Croatian freshwater bodies (MAGUIRE \& GotTStein-MatočEc, 2004; Maguire et al., 2011; KlobučAr et al., 2013; Maguire et al., 2018). Distribution data (i.e. the point occurrences) of each $A$. torrentium population were prepared using a geographic information system (ArcGIS). The dataset was split into three subsets according to the chronology of population sampling: (I) distribution dataset based on the historical data collected from the literature (GRUBE, 1861; ŠošTARIĆ, 1888; CAR, 1901; Brusina, 1907; EntZ, 1914; S. Karaman, 1929; M. Karaman, 1961, 1962, 1963; Albrecht, 1982, Sket, 1988; Sekulić et al., 1989; Delić, 1993; Gottstein, 1998; Gottstein \& Kerovec, 1998; Gottstein et al., 1999; Maguire et al., 2002; Maguire \& GottSTEIN-MAтос̌EC, 2004), and the fieldwork conducted in order to establish Natura 2000 sites (before 2014) (MAGUiRe et al., 2011); (II) a distribution dataset that included additional populations discovered during the NIP project (EU Natura 2000 Integration Project with the main aim of gathering new distributional data about concerned taxonomic groups in Croatia in order to assess threat status and plan conservation activities; 2014-2016) (Maguire et al., 2018); (III) combined distribution dataset (all literature and documented occurrences available before 2016; I+II).

\section{Gap Analysis}

Gap analysis was applied to assess how much of $A$. torrentium diversity is covered by Natura 2000 network with a computation of the amount of populations included or excluded in order to detect areas that need better protection. It is a methodology that "identifies the gaps in representation of biological diversity (biodiversity) in areas managed exclusively or primarily for the long-term maintenance of populations of native species and natural ecosystems" (Sсотт et al., 1993). In gap analysis, a species is considered as a 'covered' by the conservation network if at least one occurrence was recorded inside the reserve network, while species is considered as a 'gap' if it is not represented in any of the protected areas (RoDRIGUEs et al., 2004).

First, in order to determine how well Natura 2000 represents A. torrentium diversity in Croatia, we overlapped its occurrence data with the map of the Natura 2000 sites using ArcGIS. We used the distribution datasets mentioned above (I, II, III) together with GIS data layers (the entire Natura 2000 network for Croatia and SCI for A. torrentium; available at http://www.bioportal.hr/gis/) supplied by Institute for Environment and Nature Conservation. Layers were processed, and then combined to produce a single layer of Natura 2000 in Croatia as currently defined. Second, we evaluated the percentage of populations outside and inside Natura 2000 by analysing several settings: (a) distribution map of dataset I overlapped with a map of $A$. torrentium-designated Natura 2000 sites (SCI); (b) distribution map of dataset II overlapped with a map of $A$. torrentium-designated Natura 2000 sites (SCI); (c) distribution map of dataset III overlapped with a map of $A$. torrentium-designated Natura 2000 sites (SCI); (d) distribution map of dataset III overlapped with a map of the entire Natura 2000 network in Croatia. 


\section{RESULTS AND DISCUSSION}

\section{Natura 2000 and Stone Crayfish distribution overlapped}

To the best of our knowledge, there have been no previously published studies on the effectiveness of the Natura 2000 network on preventing further stone crayfish losses. Thus, this study represents the first evaluation of the conservation value of Natura 2000 for a species sensitive to environmental and human activities, one that is ecologically important and presents a key component of the biodiversity in the freshwater habitats (REYNOLDs et al., 2013).

One of the first stages of systematic conservation planning for A.torrentium was the review of conservation areas in th e Natura 2000 network. Our gap analysis, including 61 populations of $A$. torrentium in Croatia belonging to seven major mtDNA phylogroups, showed that the Natura 2000 network performs well in representing its diversity, which is confirmed by high percentage of covered populations (Figs. 2-5, Tab. 1).

Overlapping the distribution map of $A$. torrentium populations (dataset I; occurrences recorded before 2014) with the A. torrentium-designated Natura 2000 sites (SCI) revealed that 39 populations $(79.6 \%)$ were covered, while $10(20.4 \%)$ were located outside the designated sites (Fig. 2, Tab. 1). It should be noticed that A. torrentium populations recorded in dataset I served as the basis for the designation of Natura 2000 sites.

Tab. 1. Number of populations per mitochondrial phylogroup in four different settings (a-d): (a) distribution map of dataset I overlapped with a map of Austropotamobius torrentium-designated Natura 2000 sites (SCI); (b) distribution map of dataset II overlapped with a map of $A$. torrentium-designated Natura 2000 sites (SCI); (c) distribution map of dataset III overlapped with a map of Natura 2000 sites designated for $A$. torrentium (SCI); (d) distribution map of dataset III overlapped with a map of the entire Natura 2000 network in Croatia. Central and south-eastern Europe (CSE), Gorski Kotar (GK), Lika and Dalmatia (LD), Žumberak, Plitvice and Bjelolasica (ŽPB), Banovina (BAN), Zeleni Vir (ZV), Kordun (KOR).

\begin{tabular}{|c|c|c|c|c|c|}
\hline & Phylogroup & $\mathrm{a}$ & $\mathrm{b}$ & c & $\mathrm{d}$ \\
\hline \multirow{7}{*}{$\begin{array}{l}\text { Number of populations covered } \\
\text { by Natura } 2000\end{array}$} & GK & 13 & 2 & 15 & 15 \\
\hline & $\mathrm{ZV}$ & 1 & l & 1 & 1 \\
\hline & ŽPB & 8 & 2 & 10 & 11 \\
\hline & LD & 5 & I & 5 & 7 \\
\hline & CSE & 11 & 1 & 12 & 13 \\
\hline & BAN & 1 & 1 & 1 & 1 \\
\hline & KOR & l & 1 & 0 & 0 \\
\hline Total & & $39(79.6 \%)$ & 5 & $44(73.3 \%)$ & $48(80.0 \%)$ \\
\hline \multirow{7}{*}{$\begin{array}{l}\text { Number of populations not } \\
\text { covered by Natura } 2000\end{array}$} & GK & 0 & 1 & 0 & 0 \\
\hline & $\mathrm{ZV}$ & 0 & 1 & 0 & 0 \\
\hline & ŽPB & 2 & I & 2 & 1 \\
\hline & LD & 3 & I & 3 & 1 \\
\hline & CSE & 3 & 2 & 5 & 4 \\
\hline & BAN & 2 & I & 2 & 2 \\
\hline & KOR & 1 & 4 & 4 & 4 \\
\hline Total & & $10(20.4 \%)$ & 6 & $16(26.7 \%)$ & $12(20.0 \%)$ \\
\hline Total number of populations & & 49 & 11 & 60 & 60 \\
\hline
\end{tabular}




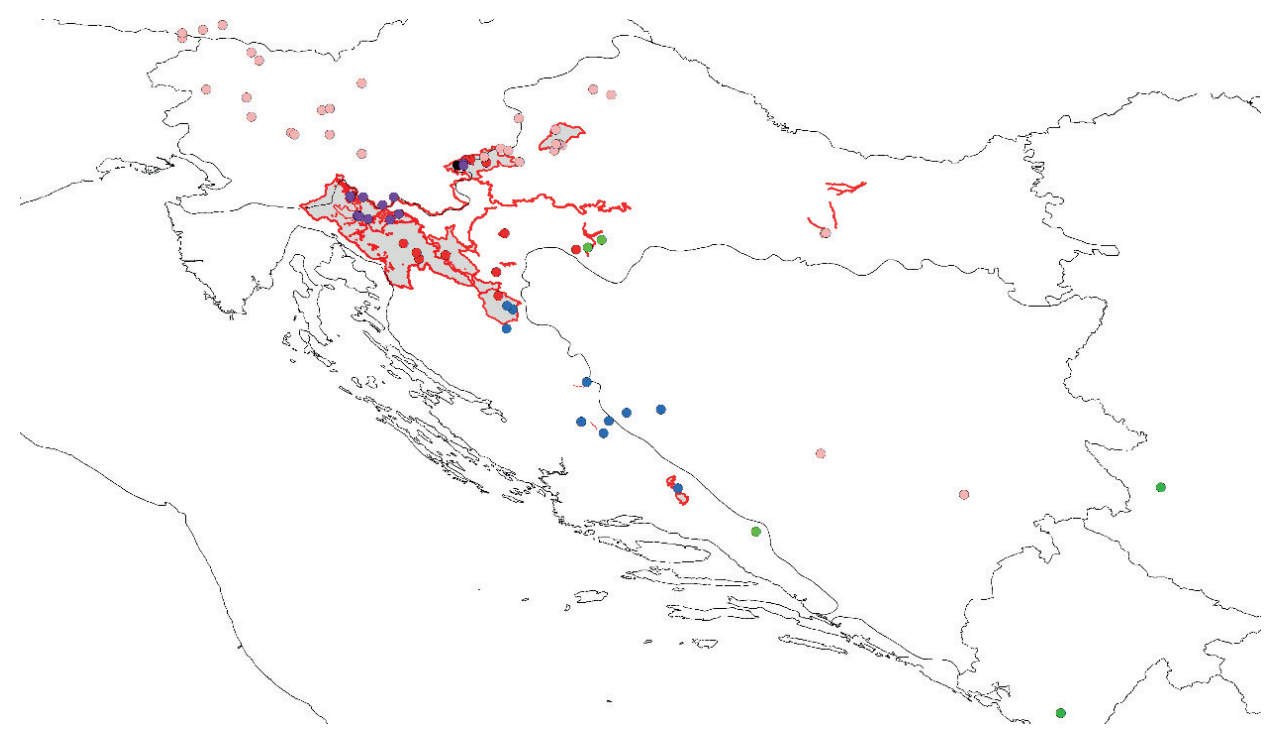

Fig. 2. Distribution map of recorded A. torrentium populations (dataset I) overlapped with the designated Natura 2000 sites for $A$. torrentium (SCI). Dots represent distribution data based on the literature and fieldwork conducted in order to establish Natura 2000 sites for A. torrentium (recorded occurrences before 2014). Colours depict different mitochondrial phylogroups present in Croatia: pink central and south-eastern Europe (CSE), purple - Gorski Kotar (GK), blue - Lika and Dalmatia (LD), red - Žumberak, Plitvice and Bjelolasica (ŽPB), green - Banovina (BAN) and black - Zeleni Vir (ZV). Natura 2000-designated sites are represented by red lines and grey areas.

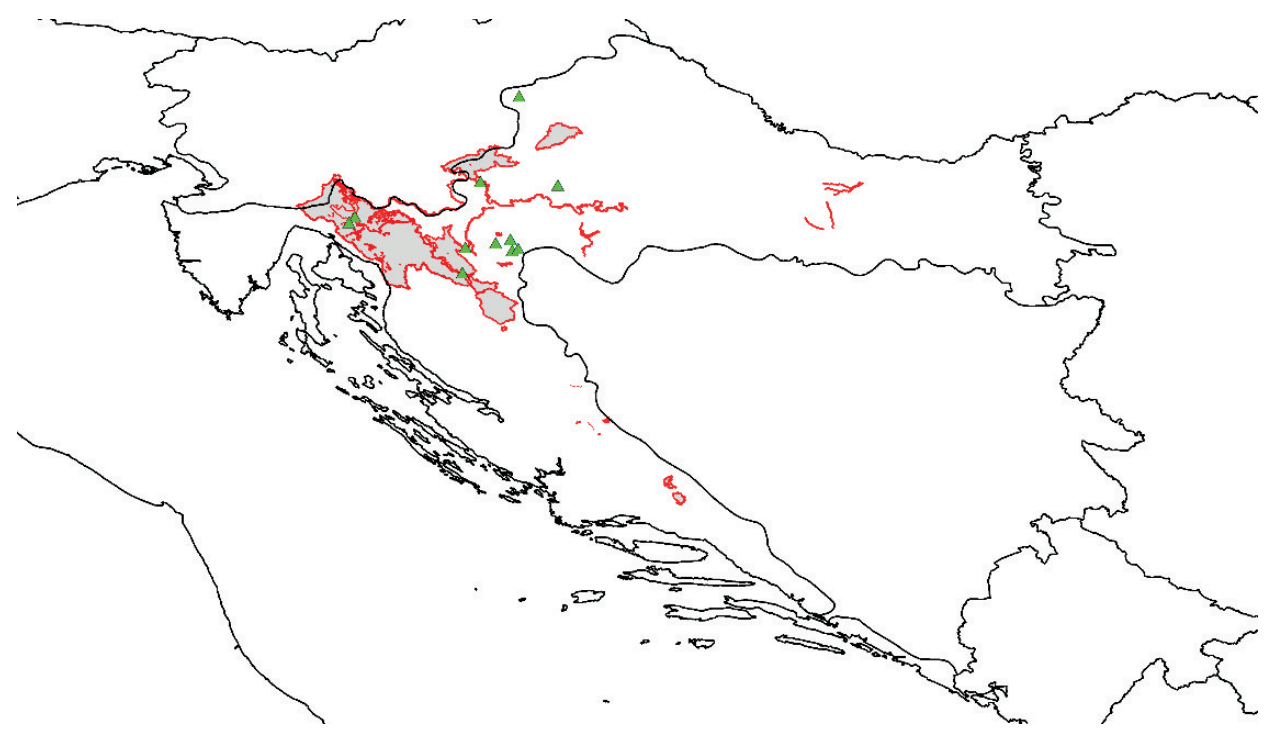

Fig. 3. Distribution map of additional A. torrentium populations discovered during the NIP project (dataset II; occurrences represented by green triangles recorded from 2014 to 2016) overlapped with the Natura 2000 sites designated for A. torrentium (SCI) that are represented by red lines and grey areas. 


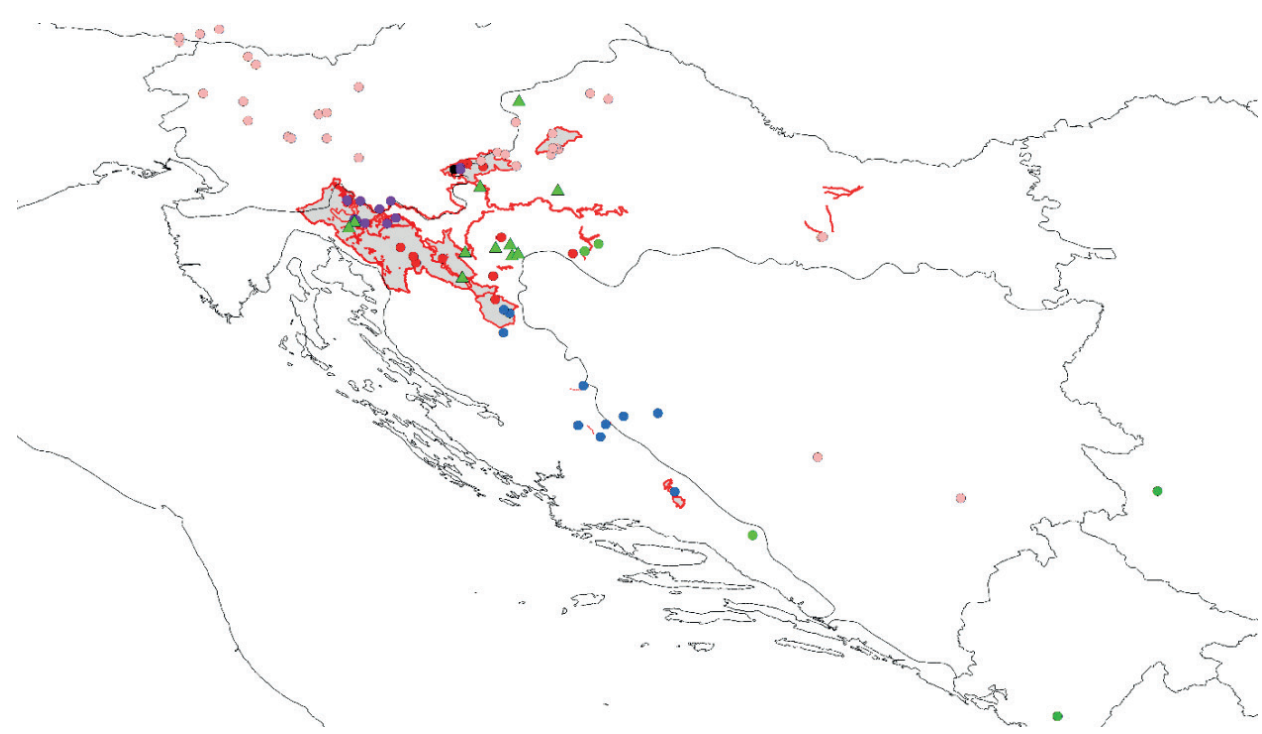

Fig. 4. Distribution map of all recorded A. torrentium populations in Croatia (dataset III; occurrences based on the literature and fieldwork conducted in order to establish Natura 2000 sites (different coloured dots represent different mitochondrial phylogroups) with additional populations discovered during the NIP project (green triangles) (all documented occurrences before 2016) overlapped with the Natura 2000 sites designated for A. torrentium (SCI; represented by red lines and grey areas).

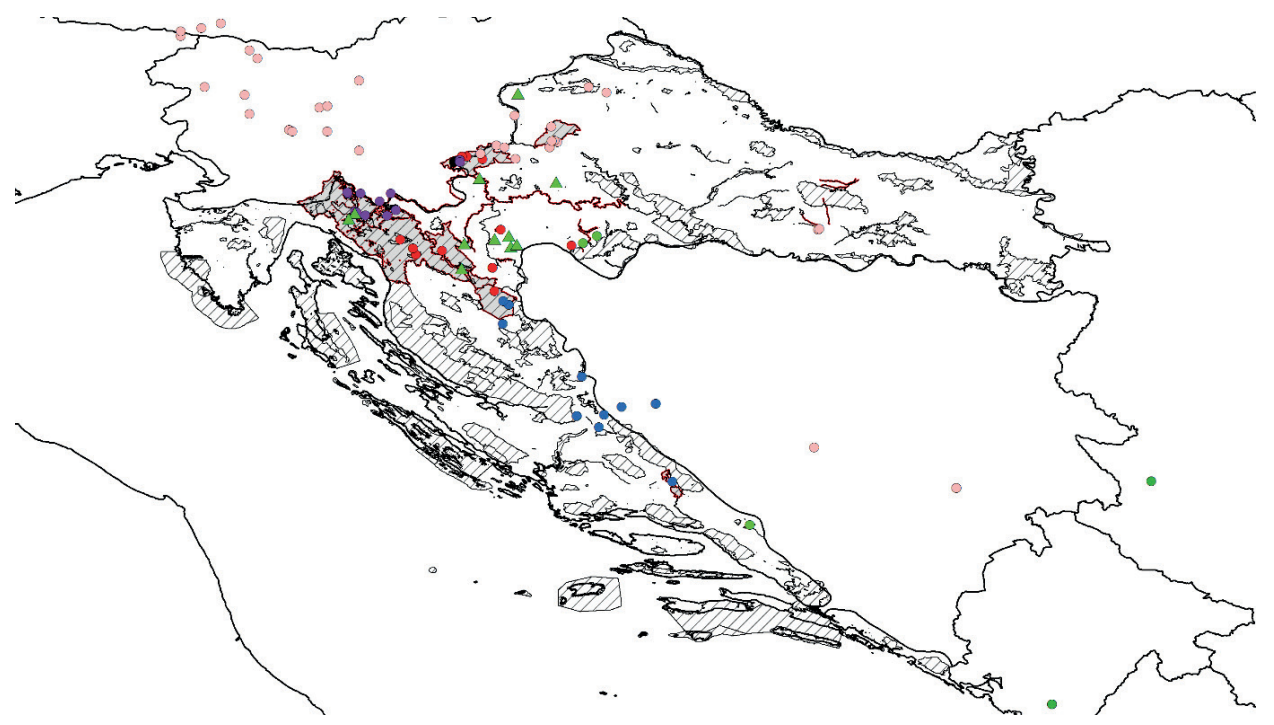

Fig. 5. Distribution map of all recorded A. torrentium populations in Croatia (dataset III; occurrences based on the literature and fieldwork conducted in order to establish Natura 2000 sites (different coloured dots represent different mitochondrial phylogroups) and additional populations discovered during the NIP project (green triangles) (all documented occurrences before 2016) overlapped with the entire Natura 2000 network in Croatia (SPAs and SACs for Croatia with SCI for A. torrentium). Natura 2000 designated sites (SCI for $A$. torrentium) are represented by red lines and grey areas, while SPAs and SACs for Croatia are represented by areas with black diagonal lines. 
During the NIP project 11 new populations of $A$. torrentium were recorded (dataset II; recorded occurrences 2014-2016) (Maguire et al., 2018). Gap analysis revealed an additional five populations located inside the Natura 2000 sites designated previously for A. torrentium, while six populations were outside the protected area (Fig. 3, Tab. 1). Detailed molecular analyses of collected crayfish samples during NIP project revealed the existence of a new mtDNA phylogroup (phylogroup KOR in Fig. 1; Lovrenčić et al., 2020) that was not covered by the currently designated Natura 2000 sites for $A$. torrentium.

Our results using a combined distribution dataset (dataset III; all literature and documented occurrences available before 2016) showed that $A$. torrentium-designated Natura 2000 sites (SCI) covered the species range relatively well, with currently designated sites harbouring 73.3\% of recorded populations in Croatia (Fig. 4, Tab. 1).

Overlapping the map of the entire Natura 2000 network in Croatia with a complete distribution map of $A$. torrentium (dataset III) revealed four additional populations included in the Natura 2000 network (altogether 48 populations out of 60 ). Hence, altogether $80.0 \%$ of recorded $A$. torrentium populations were covered by the Natura 2000 network (Fig. 5, Tab. 1).

The distribution of mitochondrial phylogroups and the number of populations per phylogroup are displayed in Fig. 1 and Tab. 1. Overlapping all the known distribution data with the entire Natura 2000 network in Croatia showed that the mtDNA phylogrups with the highest percentage of coverage were $\mathrm{GK}$ and $\mathrm{ZV}$, which are among the oldest phylogroups in the species phylogenetic tree (all point occurrences covered by some level of protection), while the phylogroup with the least coverage was KOR (all occurrences outside Natura 2000). Phylogroup KOR represents a newly discovered genetically divergent lineage distributed in the Kordun region (Lovrenčić et al., 2020).

\section{How Natura 2000 works for Crayfish in Croatia?}

Freshwater ecosystems are among the most diverse habitats in the world and, at the same time, the most threatened by human activities (Strayer \& Dudgeon, 2010). High intra- and inter-specific diversity are particularly widespread in freshwater environments, where the isolation of species with limited capacity for dispersal, such as freshwater crayfish, often leads to high genetic divergence. Erosion of the freshwater biodiversity at European level associated with habitat degradation, overexploitation, invasive alien species, pollution and climate change indicate the need to find an effective way of managing species. Therefore, the aim of maintaining existing biodiversity underlies most of the conservation efforts (e.g., Natura 2000) nowadays.

Our study results revelaed that the current Natura 2000 network in Croatia encompasses most of the areas with high diversity of $A$. torrentium, and in that sense, provides good protection (Figs. 2-5, Tab. 1). Even though this finding is in agreement with other studies evaluating the effectiveness of Natura 2000 (VERovnik et al., 2011; MAZARIs et al., 2013; Kallimanis et al., 2015; Fois et al., 2017), there are numerous gap analyses revealing that coverage of species and ecosystems by existing networks of protected areas is insufficient for the long-term maintenance of biodiversity (DIETz \& CZECH 2005; Maiorano et al., 2006; O’Dea et al., 2006; Araújo et al., 2011; JantKe et al., 2011). Since some of the studies showing poor Natura 2000 network effectiveness were based on species that are not listed in EU directives (Mendoza-Fernandez et al., 2009; JANTKE et al., 2011; Bagella et al., 2013; Maiorano et al. 2015), it was expected that our species of 
interest would have a high level of coverage. Austropotamobius torrentium is, indeed, a Natura 2000 species, protected on both national and international level, with sites designated for ensuring its survival and persistence.

The Natura 2000 network in Croatia is conceived in such a way as to be able to prevent further $A$. torrentium diversity loss; nonetheless gap analysis based on protected area coverage alone does not necessarily reflect this efficacy (CARRIzo et al., 2017; Hermoso et al., 2019). Although the Natura 2000 coverage may be satisfactory in terms of encompassing the recorded occurrences of this species, there are several drawbacks. For example, from a practical point of view, single occurrences within reserve networks and site protection alone are considered insufficient to ensure long-term survival and to safeguard freshwater biodiversity, especially of species with demanding habitat requirements, and do not take into account climate change (RodRigues et al., 2004a; CARrizo et al., 2017). Global climate changes impact the size and extent of areas that may potentially be inhabited by species (PARMESAN, 2006). So, in the case of A.torrentium, which is a cold-adapted species, we may assume distribution shifts to higher and colder habitats in the future under further climate change.

Moreover, an additional limitation of gap analysis is that it does not predict species viability and does not reveal previous habitat losses, which can lead to a misleading result in the context of present distribution (JENNINGs et al., 2000). Furthermore, despite the overlap with protected areas, many Natura 2000 sites in freshwater ecosystems of southern and eastern Europe are managed poorly (CARRIzo et al., 2017). Since habitat destruction, climate change and invasive alien species present major threats to freshwater biodiversity (CARDinale et al., 2012; CAstro et al., 2015), the efficacy of the Natura 2000 network must be enhanced by better local management of freshwater resources. Essential practical actions would require a range of activities/measures, from habitat restoration works to managing invasive species. An important and unavoidable activity that should be incorporated is building collaboration among various participants involved, including such stakeholders as local and state agencies, researchers, landholders and funding bodies (Blicharska et al., 2016; CARrizo et al., 2017).

Even though the gaps in the diversity coverage could be overcome by extension of Natura 2000 network, there is a strong emphasis on directing resources to the most threatened populations with high conservation value instead of constantly increasing the size of protected areas. Improving existing conservation sites rather than designating new ones should be the primary focus of the future efforts in increasing conservation outcomes (Hermoso et al., 2019). The Natura 2000 network is considered a rigid network due to the limited potential of adding new sites or adjusting the locations of existing sites (ORLIKowsKa et al., 2016). However, there is a potential to improve its effectiveness through better management of sites and by implementing local legislation and regulations (Fors et al., 2017). Currently, management practices which are not receiving adequate attention in policy or implementation, low level and quality of public participation with lack of flexibility on the part of the authorities are the greatest challenges to the functioning of the Natura 2000 network (BLICHARsKA et al., 2016). One of the focal points in the future conservation of threatened species such as the stone crayfish should be public acceptance and engagement (DAvis et al., 2014; BLICHARsKA et al., 2016; Fois et al., 2017). Developing and implementing guidelines for public participation are needed for successful conservation and improvement of the existing Natura 2000 network across Europe. 


\section{CONCLUSIONS}

This study provides the first gap analysis that estimates the effectiveness of the Natura 2000 network in supporting and maintaining A. torrentium diversity in Croatia using a comprehensive and recently available species occurrence dataset. This analysis can serve as a model for other Natura 2000 species and as a base for possible extension of the Natura 2000 network.

Our results showed that the Natura 2000 network in Croatia covers species distribution relatively well, and, with good management, we could consider the Natura 2000 network well suited for the long-term conservation of $A$. torrentium diversity.

Since conservation planning implies securing the evolutionary potential of the species, it is important to point out that a recently discovered phylogroup from the Kordun region is not covered by the current Natura 2000 network; thus this region should be proposed as an additional area of protection in the future extension of the Natura 2000 network.

In order to achieve effective conservation plans, one of our future goals is to develop species distribution models under different climate change scenarios to effectively address future distribution under climate changes. Furthermore, since population genetics plays an important role in conservation planning, greater insight into genetic structure of the populations is needed for the identification of the populations that have the highest conservation value.

\section{ACKNOWLEDGEMENT}

This research was funded by the Croatian Science Foundation (CLINEinBIOta - IP2016-06-2563) and Leona Lovrenčić through ESF (DOK-2018-01-9589). We would like to thank the reviewers for constructive criticism that helped to improve the manuscript.

Received October 14, 2020

\section{REFERENCES}

Abellán, P. \& SÁnchez-Fernández, D., 2015: A gap analysis comparing the effectiveness of Natura 2000 and national protected area networks in representing European amphibians and reptiles. Biodiversity and Conservation 24, 1377-1390.

Albrecht, H., 1982: Das system der eurpäischen Flußkrebse (Decapoda, Astacidae): Vorschlag und Begründung. Mitteilungen aus dem Hamburgischen Zoologischen Museum und Institut 79, 187-210.

Araújo, M.B., Alagador, D., Cabeza, M., Nogués-Bravo, D. \& Thuiller, W., 2011: Climate change threatens European conservation areas. Ecology Letters 14, 484-492.

Bagella, S., Caria, M.C. \& Filigheddu, R., 2013: Gap analysis revealed a low efficiency of Natura 2000 network for the conservation of endemic species in Mediterranean temporary freshwater habitats. Plant Biosystems-An International Journal Dealing with all Aspects of Plant Biology 147, 1092-1094.

Berger, C., ŠtAmbuk, A., Maguire, I., Weiss, S. \& Füreder, L., 2018: Integrating genetics and morphometrics in species conservation - A case study on the stone crayfish Austropotamobius torrentium. Limnologica 69, 28-38.

Blicharska, M., Orlikowska, E.H., Roberge, J.M. \& Grodzinska-Jurczak, M., 2016: Contribution of social science to large scale biodiversity conservation: A review of research about the Natura 2000 network. Biological Conservation 199, 110-122.

Bosso, L., Mucedda, M., Fichera, G., Kiefer, A. \& Russo, D., 2016: A gap analysis for threatened bat populations on Sardinia. Hystrix, the Italian Journal of Mammalogy 27, 212-214.

Brusina, S., 1907: Prilog za faunu rakâ Dalmacije i Jadranskog mora. Rad (JAZU) 171, 166-197. 
CAR, L., 1901: Prilog za faunu Crustaceja. In: A. HeInz (ed.), Glasnik Hrvatskog naravoslovnog društva 84, 4-6.

Cardinale, B.J., Duffy, J.E., Gonzalez, A., Hooper, D.U., Perrings, C., Venail, P., et al., 2012: Biodiversity loss and its impact on humanity. Nature 486, 59-67.

Castro, A.J., Martín-López, B., López, E., Plieninger, T., Alcaraz-Segura, D., Vaughn, C.C.\& Cabello, J., 2015: Do protected areas networks ensure the supply of ecosystem services? Spatial patterns of two nature reserve systems in semi-arid Spain. Applied Geography 60, 1-9.

Carrizo, S.F., Lengyel, S., Kapusi, F., Szabolcs, M., Kasperidus, H.D., Scholz, M., Marković, D., FreyHof, J., Cid, N., Cardoso, A. \& Darwall, W., 2017: Critical catchments for freshwater biodiversity conservation in Europe: identification, prioritisation and gap analysis. Journal of Applied Ecology 54, 1209-1218.

Davis, M., Naumann, S., Mcfarland, K., Graf, A. \& Evans, D., 2014: Literature Review, the ecological effectiveness of the Natura 2000 Network. ETC/BD report to the EEA, 30.

Delić, A., 1993: Rasprostranjenost potočnog raka (Astacus astacus L., 1758) u slijevu Ilove i Česme. Ribarstvo 48, 1-4.

Dietz, R.W. \& Czech, B., 2005: Conservation deficits for the continental United States: an ecosystem gap analysis. Conservation Biology 19, 1478-1487.

EnTZ, G., 1914: Über die Flusskrebse Ungarns. Mathematische und Naturwissenschaftliche Berichte aus Ungarn 30, Leipzig, p. 67-127.

Fois, M., Bacchetta, G., Cogoni, D. \& Fenu, G., 2018: Current and future effectiveness of the Natura 2000 network for protecting plant species in Sardinia: a nice and complex strategy in its raw state? Journal of Environmental Planning and Management 61, 332-347.

Gottstein, S., 1998: Taksonomske i ekološke značajke populacija deseteronožnih rakova delte Neretve. p. 1-109. (M. Sc. Theses, University of Zagreb).

Gottstein, S. \& Kerovec, M., 1998: Distribution of freshwater and brackish decapods in north-western Croatia: preliminary research in Istria, Kvarner and Gorski kotar regions. In: ARKo-PIJEvac, M., Kovačić, M. \& CRnković, D. (eds.), Natural history researches of the Rijeka region. Natural History Library Rijeka. p. 553-558.

Gottstein, S., Kerovec, M., Maguire, I. \& Bukvić, I., 1999. Ecological notes on Austropotamobius pallipes italicus (Faxon, 1914) (Decapoda, Astacidae) in the karstic spring of Neretva delta (Croatia). Freshwater Crayfish 12, 620-628.

Grube, A. E., 1861: Ein ausflug nach Triest und dem Quarnero: 125. (Nicolaische Verlagsbuchhandlung, Berlin).

Gruber, B., Evans, D., Henle, K., Bauch, B., Schmeller, D., Dziock, F., Henry, P.-I., Szabolcs, C.M. \& Dormann, C.F., 2012: “Mind the gap!"-How well does Natura 2000 cover species of European interest? Nature Conservation 3, 45.

Hermoso, V., Morán-Ordóñez, A., Canessa, S., \& Brotons, L., 2019: Realising the potential of Natura 2000 to achieve EU conservation goals as 2020 approaches. Scientific Reports 9, 1-10.

JANTKe, K., Schleupner, C. \& Schneider, U.A., 2011: Gap analysis of European wetland species: priority regions for expanding the Natura 2000 network. Biodiversity and Conservation 20, 581-605.

JENnings, M.D., 2000: Gap analysis: concepts, methods, and recent results. Landscape Ecology 15, 5-20.

Kallimanis, A.S., Touloumis, K., Tzanopoulos, J., Mazaris, A.D., Apostolopoulou, E., Stefanidou, S., Scott, A.V., Ротts, S.G. \& PANTis, J. D., 2015: Vegetation coverage change in the EU: patterns inside and outside Natura 2000 protected areas. Biodiversity and Conservation 24, 579-591.

Karaman, M.S., 1961: Slatkovodni rakovi Jugoslavije. Publikacije stručnog udruženja za unapređenje slatkovodnog ribarstva Jugoslavije 3, 1-33.

Karaman, M.S., 1962: Ein Beitrag zur Systematik Astacidae (Decapoda). Crustaceana 3, 173-191.

Karaman, M.S., 1963: Studie der Astacidae (Crustacea, Decapoda) II. Teil. Hydrobiologia 22, 111-132

Karaman, S. 1929: Die Potamobiiden Jugoslaviens. Glasnik Zemaljskog Muzeja u Bosni i Hercegovini 41: 147-150.

Klobučar, G.I.V., Podnar, M., Jelić, M., Franjević, D., Faller, M., Štambuk, A., Gottstein, S., Simić, V. \& Maguire, I., 2013: Role of the Dinaric Karst (western Balkans) in shaping the phylogeographic structure of the threatened crayfish Austropotamobius torrentium. Freshwater Biology 58, 1089-1105.

Kouba, A., Petrusek, A. \& KozÁk, P., 2014: Continental-wide distribution of crayfish species in Europe: update and maps. Knowledge and Management of Aquatic Ecosystems 413, 05. 
Lovrenčić, L., Bonassin, L., Boštjančić, L.Lj., Podnar, M., Jelić, M., Klobučar, G., Jaklić, M., SlavevskaStamenković, V., Hinić, J., Maguire, I., 2020: New insights into the genetic diversity of the stone crayfish: taxonomic and conservation implications. BMC Evolutionary Biology 20, 146.

Maguire, I., Erben, R., Klobučar, G. I. V. \& J. Lajtner, 2002: A year cycle of Austropotamobius torrentium (Schrank) in streams on Medvednica mountain (Croatia). Bulletin Français de la Pêche et de la Pisciculture 367, 943-957.

Maguire, I. \& S. Gottstein-Matočec, 2004: The distribution pattern of freshwater crayfish in Croatia. Crustaceana 77, 25-47.

Maguire, I., Jelić, M. \& Klobučar, G.I.V., 2011: Update on the distribution of freshwater crayfish in Croatia. Knowledge and Management of Aquatic Ecosystems 401, 31.

Maguire, I., Klobučar, G.I.V., Žganec, K., Jelić, M., Lucić, A. \& Hudina S., 2018: Recent changes in distribution pattern of freshwater crayfish in Croatia - threats and perspectives. Knowledge and Management of Aquatic Ecosystems 419, 2.

Maiorano, L., FAlCUCCI, A. \& BoitAni, L., 2006: Gap analysis of terrestrial vertebrates in Italy: priorities for conservation planning in a human dominated landscape. Biological Conservation 133, 455-473.

Maiorano, L., Amori, G., Montemaggiori, A., Rondinini, C., Santini, L., Saura, S. \& Boitani, L., 2015 : On how much biodiversity is covered in Europe by national protected areas and by the Natura 2000 network: insights from terrestrial vertebrates. Conservation Biology 29, 986-995.

Mazaris, A.D., Papanikolaou, A.D., Barbet-Massin, M., Kallimanis, A. S., Jiguet, F., Schmeller, D. S. \& PAntis, J. D., 2013: Evaluating the connectivity of a protected areas' network under the prism of global change: the efficiency of the European Natura 2000 network for four birds of prey. PLoS One 8, e59640. doi:10.1371/journal.pone.0059640.

Mendoza-Fernández, A., Martínez-Hernández, F., Garrido-Becerra, J. A., Pérez-García, F. J., Medina-Cazorla, J. M., De Giles, J. P., \& Mota, J. F., 2009: Is the endangered flora of the Iberian southeast adequately protected? Gaps in the Network of Protected Natural Areas of Andalusia (RENPA): the case of the province of Almería. Acta Botanica Gallica 156, 637-648.

O’Dea N., M.B. Araujo \& R.J. Whittaker, 2006: How well do Important Bird Areas represent species and minimize conservation conflict in the tropical Andes? Diversity and Distributions 12, 205-214.

Oldfield T.E.E., R.J. Smith, S.R. Harrop \& N. Leader-Williams, 2004: A gap analysis of terrestrial protected areas in England and its implications for conservation policy. Biological Conservation 120, 303-447.

Orlikowska, E.H., Roberge, J.M., Blicharska, M. \& Mikusiński, G., 2016: Gaps in ecological research on the world's largest internationally coordinated network of protected areas: A review of Natura 2000. Biological Conservation 200, 216-227.

PARmesan, C., 2006: Ecological and evolutionary responses to recent climate change. Annual Review of Ecology, Evolution, and Systematics 37, 637-669.

PÂrvulescu, L., Pérez-Moreno, J.L., Panaiotu, C., Drăguț, L., Schrimpf, A., Popovici, I.D., Zaharia, C., Weiperth, A., Gál, B., Schubart, C.D., Bracken-Grissom, H., 2019: A journey on plate tectonics sheds light on European crayfish phylogeography. Ecology and Evolution 9, 1957-1971.

Poini, K.A., Richter, B.D., Anderson, M.G. \& Richter, H.E., 2000: Biodiversity conservation at multiple scales: functional sites, landscapes, and networks. BioScience 50, 133-146.

Reynolds, J., Souty-Grosset, C. \& Richardson, A., 2013: Ecological roles of crayfish in freshwater and terrestrial habitats. Freshwater Crayfish 19, 197-218.

Rodrigues, A. S., Andelman, S. J., Bakarr, M. I., Boitani, L., Brooks, T. M., Cowling, R. M., et al., 2004 : Effectiveness of the global protected area network in representing species diversity. Nature 428,640 643.

Rodrigues, A. S., Akcakaya, H. R., Andelman, S. J., Bakarr, M. I., Boitani, L., Brooks, T. M., ... \& HoffMANN, M., 2004: Global gap analysis: priority regions for expanding the global protected-area network. BioScience 54, 1092-1100.

Schrank, F., 1803: Fauna Boica Durchgedachte geschichte der in Baiern einheimischen und zahmen Thiere. Vol. 3. Nürnberg: Steinschen Buchandlung.

Scott, J.M., Davis, F., Csuti, B., Noss, R., Butterfield, B., Groves, C., Anderson, H., Caicco, S., D'erchia, F., Edwards, T.C. JR., UlLiman J., \& WRIGHT, R.G., 1993: Gap analysis: a geographic approach to protection of biological diversity. Wildlife Monographs 123, 3-41.

Sekulić, B., Obradović, J. \& Rac, M., 1989: Proportion of exeskeleton according to the size and sex of the crayfish Austropotamobius torrentium Schr. Periodicum Biologorum 91, 113-114. 
SKeт, B., 1988: Zoogeography of the freshwater and brackish Crustacea in the Kvarner-Velebit islands (NW Adriatic, Yugoslavia). Biološki vestnik 36, 63-76.

Strayer, D. L. \& Dudgeon, D., 2010: Freshwater biodiversity conservation: recent progress and future challenges. Journal of the North American Benthological Society 29, 344-358.

ŠošTARIć, D., 1888: Prilog poznavanju slatkovodnih korepnjaka Hrvatske. Tisak dioničke tiskare, Zagreb. p. 1-112.

Trontelj, P., Machino, Y., Sket, B., 2005: Phylogenetic and phylogeographic relationships in the crayfish genus Austropotamobius inferred from mitochondrial COI gene sequences. Molecular Phylogenetics and Evolution 34, 212-226.

Verovnik, R., Govedič, M. \& Šalamun, A., 2011: Is the Natura 2000 network sufficient for conservation of butterfly diversity? A case study in Slovenia. Journal of Insect Conservation 15, 345-350. 
